UDK: 821.581

COPYRIGHT@ ANNA SIMONA MARGARITO

\title{
Reflections of the West in Gu Cheng's Life and Poems
}

\author{
Anna Simona MARGARITO*
}

\begin{abstract}
Gu Cheng (1957-1993), a prominent member of the "Misty Poets", lived the last part of his life in the West as he was exiled in 1989. So he stayed abroad separeted from his country and people and unable to cope with the western world. Western influences can be seen even in his early production (where we can see similarities with the works of J.H. Fabre) as well as in his last cycle of poems Cheng (City), in which we can find the influence of T.S. Eliot.
\end{abstract}

Keywords: Misty poetry, Chinese modernism, nature, exile, annihilation

\section{Izvleček}

Gu Cheng (1957-1993), znameniti član »Meglenih pesnikov«, je zadnji del svojega življenja - od leta 1989 naprej - preživel v eksilu na Zahodu. V tujini je bil ločen od svoje domovine in sonarodnjakov, po drugi strani pa ni bil sposoben shajati z zahodnim svetom. Zahodni vplivi pa so vidni že v njegovem zgodnjem opusu, v katerem lahko zaznamo podobnost z deli J.H. Fabreja, in tudi v zadnjem ciklusu njegovih pesmi z naslovom Cheng (Mesto), v katerem je najti vpliv T.S. Eliota.

Ključne besede: Meglena poezija, kitajski modernizem, narava, eksil, izničenje

\section{Introduction}

In this essay I want to move between text analysis and biographical background to see how western influences can be traced back in Gu Cheng's poetry since his earliest production. So I discuss here those that I consider as the main references in

\footnotetext{
* Anna Simona Margarito, PhD student, Università del Salento, Lecce, Italy. E-mail address: annasimona.margarito@tin.it
} 
his early poetry and in the latest cycle. Namely they are: the French entomologist Jean Henri Fabre, for the first part of Gu Cheng's life and production, and the modernist writer T. S. Eliot in his latest cycle of poems called Cheng 城 (City).

\section{His Early Life and Production: the Influence of J. H. Fabre}

Gu Cheng 顾城 is one of those authors whose life was deeply entangled with historical events. This is the reason why I consider as necessary, first, to sum up few main events of his biography, in order to better understand the profound meaning and high value of his poetry and the evident changes we can see in it.

$\mathrm{Gu}$ Cheng lived and worked between 1956 and 1993. Born in Beijing on September $24^{\text {th }} 1956$, his father, Gu Gong 顾工, was a well known journalist, intellectual and an editor of Jiefangjun Bao 解放军报 (Journal of the People's Liberation Army); his mother was an intellectual and scriptwriter. The family lived in Beijing 北京, in the Bei Hai 北海 district where the poet attended school but only for three years, that is, from 1963 to 1966, when the Cultural Revolution broke up and schools were closed (Li Xia 1999, 405).

He was a prodigy child, and as recorded in his anthology, he began writing poetry when he was 6 (as his earliest poem dates back to $1964^{1}$ ).

He belonged to an unfortunate generation of Chinese people born in the second half of the $20^{\text {th }}$ century. This generation was labelled by scholars as "unfortunate" because of the many traumatic events which characterized the period in which they lived starting from the Great Famine which affected China from 1959-61, followed by the Cultural Revolution of 1966-76. This generation also went through the end of the Maoist Period, towards the advent of Deng's Socialist Modernization (and made a first hand experience of the problems it involved) and last but not least witnessed the struggle for democracy and Tian'anmen Square (Massacre) in 1989.

In an interview in December 1992, answering the question: "Which were the books that influenced you initially?" Gu Cheng replied: "those of the French entomologist Fabre" (Li Xia 1999, 335). Henry Fabre was given the Nobel Prize in

\footnotetext{
${ }^{1}$ Some scholars suggested the hagiographic construction of the life of the poet as well as his life by his family. We can just mention this theory, because it is not something that we want to discuss here, as it is not relevant for this topic.
} 
1910 for his study on insects. In many different occasions Gu Cheng stated that this book had an enduring influence on him throughout his life.

Just like Gu Cheng, who had to study almost as an autodidact because of the Cultural Revolution, Fabre had been largely an autodidact because of the poverty of his family.

Fabre used to work as a teacher in order to earn his living, and in my opinion, I think this job influenced his prose. While reading his pages, we can guess that he was quite skilled at communicating and knew how to keep the attention of the reader/listener. He knew how to create interest in a subject which was definitely not familiar nor easy. As a matter of fact, he was the first scientist to observe the habits of insects. As many critics underlined, he described the life of these little creatures as if he were writing a biography or a novel. The language he used is so colloquial and down to earth that it catches the reader's attention for its simplicity, never turning into triviality. His prose is colourful, sparkling with wit. This unusual language, (which combines a scientific subject with a literary style) later influenced authors like Proust and Hugo who called him the "Homer of insects" (“Living World" 2011).

It is not difficult to realize that such a language sounded very different from the language customarily used in scientific studies. When observing and then describing these little creatures in their natural environment, Fabre expressed his emotions, those of an admiring observer, of an enchanted child, more than those of a scientist. To me his accounts seem very similar to Phaedrus's fairy tales. I think so because Phaedrus describes insects' habits and acts as a little wonderful adventurer. This little world of wonders, so fascinating for Fabre's readers, is real and true and above all, natural ("Living World" 2011).

When the Red Guards went away after confiscating all the books in $\mathrm{Gu}$ Cheng's house, the young poet found by chance under an old newspaper, a copy of the Souvernirs Entomologiques. So Fabre turned him into a "passionate lover of insects" (Crippen 2005, 152). Besides this book, throughout the period of the Cultural Revolution, Gu Cheng had at his disposal also the Cihai Dictionary 辞海 and other few books. At this time of his life, the young poet had already begun writing poems. As I mentioned before, his first poems date back to 1964. The prodigy child used to dictate his lines to his sister as he did not know how to write at that time (Crippen 2005, 150), or to recite them to his father ( $\mathrm{Li} \mathrm{Xia} \mathrm{1999,} 231-$ 2). His poems were "stories about pine-cones and rain drops; dialogues between 
clouds and the earth; intimate chats of a ladybird with an ant" (Li Xia 1999, 231). Just to make a couple of examples, we can read:

\section{杨树 ${ }^{2}$}

我失去了一只臂膀,

就睁开了一只眼睛. (Gu Gong 1995, 7)

\section{Poplar}

Losing an arm,

I open wide an eye. $(\text { Allen } 2005,1)^{3}$

\section{星月的来由}

树枝想去撕裂天空，

但却只櫂了几个微小的窟窿,

它透出了天外的光亮,

人们把它叫作月亮和星星. (Gu Gong 1995, 7)

\section{The Origins of the Moon and Stars}

Branches of trees try to shred the sky

but succeed only in poking so many tiny holes,

through which pierce lights from beyond the sky

that people simply name Moon and Stars. (Poem by Gu Cheng)

In this early production, just like in Fabre, the language $\mathrm{Gu}$ Cheng uses is close to everyday language, basic, simple, linear for as much as the language of a child can be. But the influence of Fabre can be seen in the same attitude towards the world

\footnotetext{
${ }^{2}$ For all the poems quoted here, if not further specified, the original text is taken from: Gu Gong 顾 工, Gu Cheng shi quanbian 顾城诗全编 (Selected Poems of Gu Cheng), 1995.

${ }^{3}$ All the English translations of the poems and their English titles used in this paper, if not further specified, are taken from: Joseph R. Allen, Sea of Dreams, the Selected Writings of Gu Cheng, 2005.
} 
he wants to depict in his poems. He looks around in the only way he knows, that is, like Fabre taught him to do. In these early poems he demonstrates the precise attention of the scientist mingled with the language and the vivid imagination of a poet. A keen observer of the surrounding reality, Gu reveals this world to the reader with a touch of wit and fantasy which is not constrained by the chains of maturity. Personally, I compare the Gu Cheng of these early poems to Prometheus, the titan who made the gift of knowledge, of all the human abilities and science to humanity. Just like Prometheus, he gives the reader an access to a new world made of poetry in reality which was present in nature but hidden to common people, as the poet is the only one who can clearly and best see this natural world through the lenses of his imagination. The universe depicted in these early poems is a universe seen through the eyes of a child who is discovering it little by little, piece by piece, and who is trying to understand this world and its rules using his intellect and his limited knowledge. In The Origin of the Moon and the Stars Gu Cheng is doing research. He is making his own personal hypothesis on how the moon and the stars came to be, like a scientist does. Obviously his hypotheses have no scientific value, though personally, I find it very interesting, and I find the words he uses as enchanting.

According to Gu Cheng's personal cosmogony, one day the tree branches, as if they were willing living creatures, decided to go and tear the sky maybe because they were curious to know what was hidden behind it. But unfortunately, they could only create little holes on it through which the light from behind the curtain of the sky fell. These little holes actually are what men now call "moon and stars". The language Gu Cheng uses here is so vivid that the reader has the impression of watching a movie instead of reading a poem. And I think it would be much easier to turn this poem into a short film than to translate it into any other language.

The poet acts like a new Doctor Frankenstein, as if he could imbue these little things with a new life, as if the little simple things of a human landscape or the ordinary natural phenomena got, through the lens of Gu Cheng's imagination, a different meaning and value, a new and more sparkling life. We can read the poem Poplar, just to make an example. In this short poem the natural phenomenon described is simple and quite common: a poplar tree, probably seen by the side of a road or in a public garden, loses a branch. This is an event that happens under our eyes if not regularly but normally and usually we do not even notice it. Let's see what happens through the eyes of the poet/explorer: 
Losing an arm,

I open wide an eye. (Allen 2005, 1)

The poplar becomes a new living creature, its rebirth makes it act as a human or even as the insects described by Fabre. The poplar comes to life and suddenly develops arms, eyes, a body. In its green foliage, which becomes its face, a dark hole turns into an eye, and the miracle of life happens in two lines.

But the difference between Fabre, the entomologist and scientist, and $\mathrm{Gu}$ Cheng, the poet, lies in the fact that, as Tang Xiaodu observes (Li Xia 1999, 37), "When he regarded as heavenly enlightenment the glistening raindrops hanging from a pine cone, $[\ldots]$ he obviously seriously underestimated the organic nature of the scene before his eyes".

In the poem by the title 美 Mei (Beauty) in 1969, Gu Cheng writes: 我所渴望 的美, / 是永恒与生命; ( $\cdots)$ 生命的美, 千变万化, /却终为灰烬。(Gu Gong $1995,11)$ "The beauty I thirst for, is perpetual if compared to life; [...] the beauty of life, is constantly changing, /but in the end it becomes ashes". 4

$\mathrm{Gu}$ Cheng longs for beauty and perfection in life. In his poetry, at the beginning of his life, he looks for this perfection and finds it in nature. But later comes the discovery that real life and above all humans and society are not perfect, nor eternal. And this beauty would turn into ashes and dust.

The Cultural Revolution moved Gu Cheng to the real countryside to face nature which turns out to be completely different from the one depicted by Fabre. In 1969, when the poet was twelve, when his father and his family were sent by the government to raise pigs on the shores of Bo Hai, Gu Cheng says:

"With so many dear little companions, I gave up the city for the countryside". [...] Our first night in the countryside was miserable: things scattered in the courtyard, on the road; the whole family stretched out on a mud-brick bed; everything completely still, black. It seemed like the world would never come back into being. We started learning to consider the earliest world invented by humanity — water, fire, light...

Goodbye J.H. Fabre. (Crippen 2005, 153)

His little wonderful world was deemed to crash under reality from the very beginning.

\footnotetext{
${ }^{4}$ The translation of these lines is mine.
} 
And as if he was aware of this in 1969 just before leaving Beijing, Gu Cheng writes: "I am dreaming./ My dreams are shattering./ Dreams always forgive their destruction,/ but destruction never lets go of dreams." And he adds "Sometimes a poem needs to be a little smarter than its writer." (Crippen 2005, 153)

\section{Maturity, Disillusionment and T.S. Eliot}

In 1974 the family was allowed to return to Beijing, where the young Gu began to perform menial jobs and to publish the poems written during his exile.

In 1983 he married Xie Ye 谢烨 (Li Xia 1999, 254). In 1987, when he had already become an established poet, he was permitted to leave China for Europe and participated in readings in Bonn, Vienna, Paris, London, Oxford, Copenhagen, and many other places. From 1988 to 1989 he moved to Auckland and lived on Waiheke Island with his wife Xie Ye and their son Mu'er 木耳. But “Gu Cheng had fallen in love in Beijing with a girl by the name of Li Ying 李英” (Li Xia 1999, 252). In 1990 Li Ying, (whose nickname is Ying'er 英儿) went to live with the poet and his wife. From 1992 to 1993 the poet and Xie Ye stayed abroad again, more specifically they moved to Germany as Gu had a job there. In Berlin, Gu Cheng began to miss Ying'er. Xie Ye searched for her but Ying'er had eloped with another man. In September 1993 they returned to Waiheke.

In 1992, when Gu Cheng was in Germany, but probably already in 1991 (Li Xia 1999, 24), he worked on his last cycle of poems by the title Cheng. One of the main themes is the loss of his lover Ying'er, the others are, according to the poet, Beijing Lost and the events of June $4^{\text {th }} 1989$ (Li Xia 1999, 23).

Here, through this brief analysis of the last poems, I want to see how western literature influenced even the very last part of Gu Cheng's production.

Gu Gong, his father, states that the modernist features in Gu Cheng's poetry are the same response to a quite similar social and historical environment created in Europe after the two World Wars, and in China after ten years of destruction and war (Li Xia 1999, 58). So, according to Gu Gong, these similar conditions created a sort of common mood shared by the modernists in the West and the "searching generation" in China (Li Xia 1999, 58). This situation produced more or less, but originally in both cases, the same reactions. Gu Gong also states that 
his son never read anything of Symbolism, Futurism, Expressionism, stream of consciousness, etc.

Actually, there are many assumptions of the hagiographic construction of the life of the poet by his family but I will not go further in this issue, as it is not the main point of this paper. My personal opinion is that, as certainly happened, $\mathrm{Gu}$ Cheng grew up in what his father effectively describes as a "cultural desert" and an "aesthetic wasteland" ( $\mathrm{Li} \mathrm{Xia} \mathrm{1999,58),} \mathrm{but} \mathrm{it} \mathrm{is} \mathrm{also} \mathrm{reasonable} \mathrm{to} \mathrm{think} \mathrm{that} \mathrm{if}$ not after the Cultural Revolution when the western culture flooded China, at least when living in the West, Gu Cheng read western authors in translation, and I think that the reflection of them and of their works can be seen even through the peculiarity and originality of his poems. To support this statement, here I briefly analyse his last poems, that is, the cycle Cheng written between 1992 and 1993. Because this work, in my opinion, shows many similarities with the poem The Waste Land by T.S. Eliot. We can also say that Eliot "arrived" in China in the 20s of the last century, and we can also mention that already in 1937 a translation of The Waste Land was published by Zhao Luorui 赵萝芜.

Cheng is made up of 52 poems of different length and structure and was left unfinished. Through the power of his strong imagination, $\mathrm{Gu}$ Cheng is able to walk around Beijing even though he was living on another continent, to see things and places which did not exist anymore; he is able to "refurbish" or "rebuild" the gates pulled down, the bricks, the walls, the trees, in a moment, like a god with the power of his poetry and of his enchanting words. The city in which we follow him, reading these 52 poems, is not a pleasant place, the reader perceives a deep sense of uneasiness that is also suggested by the recurrent idea of death.

The first similarities between The Waste Land and the Cheng can be found on the first structural level of analysis. The Waste Land is a long poem divided into five sections of different length and structure (Death by Water is composed of 10 lines, while The Fire Sermon is made up of 138 lines), and the cycle Cheng, is made up of poems of different length and so that we can also consider it as a whole long poem. The shortest poem is 府右街 Fu You Jie which is composed of one single line and the longest is 甘家口 Gan Jia Kou with a total of 37 lines. Both Cheng and The Waste Land are characterized by division, by fragmentation. They have no apparent coherence, seemingly there is no unity. What strikes and disorientates the reader in both cases is this lack of a solid and precise structure, as 
a reflection of the situations the poets see in the world these two works represent (Marinoni and Salmoiraghi 1992, 1008).

But there is, in fact, an underlying unity in these works. We perceive it when we find a number of recurring images scattered here and there in the poems, these are "little pieces", "little bricks" which are words repeatedly used by the authors as to create a sort of a broken path that leads the reader towards the end of the works.

The images which are used and repeated are surprisingly similar in Eliot and in Gu Cheng, namely they are: water, a river, canals, a garden, the sea, money, the cold, snow, bricks and stones, and towers.

There are also other images, not recurrent but which are curiously present both in The Waste Land and in Cheng. I would like to mention these in brief: the game of chess, the act of fishing, furniture, a mirror, chairs, clothes, snow, ice and cold, a dog, silver and gold, money, someone who died, a suitcase, a woman's hair, a bridge (London Bridge for Eliot and Marco Polo Bridge for Gu Cheng), boats, stones, temples, frost, nails, marble, stones, towers, winding roads, and grass.

I want also to highlight the fact that Eliot in The Waste Land quotes a children's song: "London Bridge is falling down" and in Gu there are often linguistic references to the songs of the Cultural Revolution through the political diction used in the Maoist era ( $\mathrm{Li} \mathrm{Xia} \mathrm{1999,} \mathrm{32),} \mathrm{like} \mathrm{in} \mathrm{the} \mathrm{poem:}$

人儿

到阳光里去

海有条尾巴

我们要学的事情挺多 (Gu Gong 1995, 861)

\section{Little People}

Off to the sunshine

the sea has a tail

We still have so much to learn (Li Xia 1999, 32)

We can also hear the echo of the songs of the Maoist period even in Baitashi 白塔 寺 (White Pagoda Temple) with “the Red Flag Ballad” (Allen 2005, 168). 
The Game of Chess is the title of one of the section of The Waste Land in which Eliot deals with love. What Eliot depicts here is not true love but rather passion, lust (Sullivan 1973, 38). In The Fire Sermon we meet "the lowest of the dead", two lovers acting mechanical actions. In Eliot (Eliot 1976, 251-2), even making love is reduced to something automatic not even pleasant if the woman thinks with a "half-formed thought" (Eliot 1976, 76), "well now that's done: and I'm glad it's over" (Eliot 1976, 76). True love is not possible in this land, even feelings are empty, arid, wasted, so that love turns out to be only sex and lust.

The theme of love is present also in Cheng through its absence, because, as I have said, the loss of his lover, Li Ying, is one of the three main themes of the cycle. The pronoun "you" in the poems refers to her (Li Xia 1999, 23). What I noticed first when reading the poems is the presence of sexual elements, or elements that are used in the Chinese literary tradition with sexual references like 花 hua (“flowers") which also means “wounds", the word 园 yuan (“garden”) and the image of 水 shui (“water").

Gu Cheng, as Li Xia notices (Li Xia 1999, 61-75), lived on Waiheke Island in isolation. He was isolated in a foreign culture he was not interested in, and he was linguistically isolated because, despite his long residence abroad, he had always refused to learn another language because he was afraid of losing his Chinese identity, his Self. To this identity he was retained even by the presence of the two women. In his life and at home he wanted to recreate a kingdom of daughters, like the one presented in the novel A Dream of Red Mansion, and the lover's elopement with another man caused the destruction of his dream world. According to Li Xia, this demonstrates how important the old China was to him and that he was incapable to leave it behind. It also tells us that his new life in the West was deemed to failure probably because of his incapability to combine his past world with his new present life. What struck Gu Cheng the most of Waiheke was its pristine nature, contrasting with cities characterized by material progress, including Berlin, where he was bored, homesick and longed for the nature of Waiheke (Li Xia 1999, 61-75).

The Waste Land apparently has no specific plot, if not for the five episodes (Marinoni and Salmoiraghi 1992, 1008). Even in Cheng there is no coherent plot, the only thing that most of the poems have in common is "the city", Beijing. As there is no plot there is not even a coherent development in the actions or places described. The length of the poems is different. For example, 府右街 Fu you jie is 
made up of one single line of 20 characters, though it is not the shortest poem, and the longest one is 甘家口 Ganjiakou with a total of 37 lines. We can make the same consideration for Eliot as the length of the five sections is quite variable and ranges from 10 lines of Death by Water to 138 lines of The Fire Sermon.

For Eliot as for Gu Cheng the length of the verses is not defined and fixed. As for the themes dealt in both of the works, there are also similarities.

Eliot wrote The Waste Land in 1922 and it belongs to the early stage of his production. The main themes dealt are: a strong link with the past and the sterility of modern life (Marinoni and Salmoiraghi 1992, 1008).

In the short prose he used as a preface to the cycle Cheng, he says: "In my dreams I often go back to Beijing, but it has nothing to do with the Beijing of today. It is a place that is heaven-sent just for me" (Allen 2005, 151). When Gu Cheng returned to Beijing from the countryside in 1974, he realized that his city had changed. Just to make an example, Taiping Lake (to which one of the poems is entitled and where the poet used to go when he skipped lessons), did not exist anymore because too many people had committed suicide there and it had been filled, and turned into a high hill (Li Xia 1999, 25). His city had changed because history and progress had turned it into something strange, something frightening, something destroyed and fragmented, and we can understand how meaningless and how "unbearable" it had become for the poet when we read his works.

Tang Xiaodu 唐哓渡 (Li Xia 1999, 41) remembers that in an interview in $1984 \mathrm{Gu}$ Cheng stated that in his poetry "the city would disappear and what would appear in the end would be a tract of grazing land" (Li Xia 1999, 41). Still Tang Xiaodu records that, in his language, Gu Cheng opposes the "city" to the "grazing land".

"The city" means narrow, confined spaces, mapped out roads, polluted air and souls wrapped in fashion garments; not only that, what is more important is that it symbolises the rule of machine power that is universal and omnipresent in the real world. This power has turned people into "cogs and screws", numbers and passwords on both existential and cultural levels. For Gu Cheng, the "city" seemed to symbolise, in a concentrated manner, all the follies and evils of industrial civilisation. [...] The "grazing land" is the opposite. (Li Xia 1999, 41-2)

Still Tang Xiaodu writes that "he said 'I'm not used to the city, I'm used to the countryside... where I was forged into shape"”. (Li Xia 1999, 42) 
Nature has always been considered by the poet as an escape, as a refuge from a capitalistic society, but the natural elements present in the cycle are not idyllic at all. We can read the following poem, also included in the cycle Cheng, as an example:

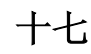

\section{老虎身上过花厅 煤田里边打黄蜂}

猴啊猴啊打黄蜂

煤田里边过花厅

老虎身上打黄蜂 (Gu Gong 1995, 866)

\section{7}

Passing by the flower halls on the bodies of tigers

in the coal fields beating wasps

Monkey, oh monkey, beating wasps

In the coal fields passing by flower halls

Beating wasps on the bodies of tigers' (Allen 2005, 158-9)

These animals kill, run, die, and above all, what we notice is that they are not in their natural environment, they are in a coal mine or they move along a corridor. Dragonflies are captured by soldiers of the highest caliber (Xiang lai jie 象来街), winter birds become “trains" “calling” in Xi Shi 西市 (West Market), a "tiger walk back and forth along the road" (Allen 2005, 167) in Hu fang qiao 虎坊桥 (Bridge at Tiger Workshop), and chickens become genocidal picking each other in Liu li qiao 六里桥 (Six Mile Bridge). Here, at this point of his life, the poet can no longer find refuge in nature. As we can see from this poem, at the time of the cycle for $\mathrm{Gu}$ Cheng even Nature has been corrupted, and turned into something else, strange and puzzling. Even the characters living in Cheng are not represented as full people but only sketched and characterized simply through their function in the society. There are characters with no names (like $n i$ 你 "you" referring to Ying'er, his young lover), or well known personalities like in the case of the reference to Chairman Mao, or general soldiers, or victims beaten or killed whose names are of no importance like the names of all others. Even in Eliot, apart from 
the main ones, minor characters have very little connotations (Bradbrook 1965, 23).

Another similarity is that T.S. Eliot's poem is characterised by a series of images which seem to be ambiguous and connected only by association of ideas (Marinoni and Salmoiraghi 1992, 1008), he uses the stream of consciousness technique. The same thing can be said for Gu Cheng's cycle where we find a mixture of real and unreal elements. As we can read from the preface, the old city of his memory (which was different from the Beijing of the 70s and 80s where the author returned to live) overlaps with the most recent image of Beijing of the time of the Tian'anmen incident and with the city of Berlin where he lives when he writes the poems. Here is a part of the preface:

When I arrived in Germany it reminded me of the Beijing of my youth. [...] In my dreams I often go back to Beijing, but it has nothing to do with the Beijing of today. It is a place that is heaven-sent just for me. Peace Lake and China Gate are now gone; also gone are the bricks in the bright sunlight, the cinder road along the hillside, and the wild jujube trees. And yet, I still move around them, looking down on all below and on days to come. [...] I have written only half of the poems in this sequence "The City". Many gates have yet to be covered. (Allen 2005, 151)

The result is a sort of hallucination which takes him back into a city that does not exist anymore, looking for a girl who is no longer his lover, a sort of dreamlike travel which lasts 52 poems. When we follow him through the poems around the city, the only thing that actually reminds of the real Beijing are the titles given to the majority of the works. As Gu Cheng leads us in his wondering around this imaginary place which is beyond time and space, we become spectators of a series of actions which at times make no sense at all for the reader, as we can see in Shoudu juchang 首都剧场 (The Capital Theatre). This happens, I think, because these actions and facts make reference to personal events in the life of the poet, or are recollections of his past so that it is almost impossible to get to the real meaning without his help. In some cases, the notes or explanations given by the author to his friends and translators are available but in most of the other cases, we can only make conjectures, as in the case of the poem Shoudu juchang 首都剧场 of which I want to mention only two parts just to give an idea of what I mean: 


\section{首都剧场}

星期六 她说 猫

过了三点 她说 猫

猫猫

老虎不动 (Gu Gong 1995, 864)

\section{The Capital Theater}

$\begin{array}{lll}\text { On Saturday } & \text { she says } & \text { kitty kitty } \\ \text { somewhat after three } & \text { she says } & \text { kitty kitty } \\ \text { kitty kitty } & \text { kitty kitty } & \end{array}$

Tiger does not budge (Allen 2005, 157)

Gu Cheng's memories of the past are not linear, quite muddled, apparently following a confused and confusing stream of thought. There are also many linguistic difficulties in understanding the real meaning of the sentences, together with the apparent stream of thought. He also uses a sort of "stream of language", if we can borrow this term used by Gao Xingjian in another context (Gao and Yang 2001, 59). On one side there is the natural ambiguity of Chinese language which has no singular or plural, no gender, no accordance between nouns and adjectives, between a verb and a noun or a subject, there are no particular suffixes indicating the tense of the verb so that all these elements and their connection in the sentence are, as we can say, logically "suggested" so that someone said that Chinese is the ideal language for poetry.

$\mathrm{Gu}$ Cheng exploits all these characteristics of his native language rendering this disorientation, this lack of certain references, up to the point that he also avoids punctuation and makes use of enjambement so that translating these poems becomes quite complicated. Because of all the ambiguity thus created, it is difficult to render this ambiguity in a language so precise as the Italian language is.

The result of all the factors I have mentioned above is a sense of confusion, disorientation, lack of temporal and spatial references he creates in the reader. Described in the poems, we find some sort of actions which can be present or past 
or both mixed together into consecutive stanzas as they overlap in the mind of the poet. For example:

\section{知春亭 \\ 那么长的走廊 有粉笔 \\ 把手伸得高高的 (Gu Gong 1995, 875)}

\section{Spring Pavillion}

A corridor so very long and chalk there

Reaching with my hand so high (Allen 2005, 164)

Making the final considerations about the many influences and references to western literature in Gu Cheng's poetry since his earliest works, I would like to use a consideration made by T.S. Eliot in a letter to The Dial written in 1922. Talking about Joyce and the way in which he re-uses myths, Eliot states that authors should not behave like "inventors" but just like "scientists", because they use someone else's discoveries to autonomously follow their own research activities (Crivelli 1993, 72). I think this could be particularly true in the case of Gu Cheng and here I make specific reference to many similarities with The Waste Land.

Gu probably used the material found in Eliot and turned it into something new, which took new shape and meaning as it was filtered through his personal experience, sensibility, language and, above all, his Chinese identity. There are many other things to say and many considerations to make, but I think it is interesting at this point to underline the personal development of the poet as it can be followed through these few works. He started out as a young entomologist, to become a fairy tale poet as underlined by Yibing Huang in his essay The Ghost Enters the City: Gu Cheng's metamorphosis in the "New world" (Lupke 2008, 123-43) and after the many vicissitudes of his life and his travels he ended out to be a man completely changed, destroyed, ruined as his old city was. In my opinion this is the Gu Cheng we can see in his final cycle. As we guess from the title which is clearly a pun on his first name (Li Xia 1999, 23), the real main theme of his latest cycle and the main protagonist of it is Gu Cheng himself, as the man beyond the poet. He tells us this man has been ruined by the world, by history and society, just like his hometown, the city of Beijing. The only main difference 
between $\mathrm{Gu}$ Cheng and Eliot lays in the fact that in Eliot we can still see hope, whereas in $\mathrm{Gu}$ Cheng there is no hope, no helping hand to come and save him to rebuild something new. This utter destruction could only lead to annihilation. $\mathrm{Gu}$ Cheng killed himself on October $8^{\text {th }} 1993$ (Li Xia 1999, 406).

\section{Conclusions}

The relation between Gu Cheng and the West has always been difficult. Though he was not completely indifferent from western influences in his poetry, he was unable to get rid of the traditional Chinese values and culture. So, as an integral part of his identity, Beijing somehow represents himself. This can be seen in his early life and works, and even in his last cycle of poems Cheng (City).

\section{References}

Allen, Joseph, ed. 2005. Sea of Dreams, the Selected Writings of Gu Cheng. New York: A New Directions Book.

Bradbrook, Muriel Clara. 1965. T.S. Eliot. London: Longmans Green and Co.

—. 1962. T.S. Eliot. Translated by Elio Chinol. Milano: Mursia Editore.

Crippen, Aaron, ed. 2005. Nameless Flowers. New York: George Braziller Inc.

Crivelli, Renzo S. 1993. Introduzione a T.S. Eliot (Introduction to T.S. Eliot). Bari: Editori Laterza.

Eliot, T. S. 1932. Selected Essays. London: Faber and Faber.

_. 1968. The Waste Land. Edited by Charles Brian Cox and Arnold P. Hinchliffe. Glasgow: MacMillan and Co.

—. 1976. The Waste Land. Edited by Mario Melchionda. Milan: Mursia.

—. 1982. La Terra Desolata (The Waste Land). Edited by Alessandro Serpieri. Milan: Rizzoli.

Frye, Northrop. 1989. T.S. Eliot. Bologna: Il Mulino.

Gao, Xinjang 高行健, and Yang, Lian 杨 炼. 2001. Il pane dell'esilio (The Bread of the Exile). Edited by Gianni Santamaria. Milano: Medusa.

Gu, Gong 顾工. 1995. Gu Cheng shi quanbian 顾城诗全编 (Selected Poems of Gu Cheng). Shanghai: Sanlian Shudian.

Knoll, Robert Edwin. 1964. Storm over The Waste Land. Chicago: Scott Foresman and Co. 
Kubin, Wolfgang. 1999. "Fragments: Remembering Gu Cheng and Xie Ye.” In Essays, Interviews, Recollections and Unpublished Material of Gu Cheng, Twentieth-Century Poet, edited by Li Xia, 247-70. New York: The Edwin Mellen Press.

Li, Xia, ed. 1999. Essays, Interviews, Recollections and Unpublished Material of Gu Cheng, Twentieth-Century Poet. New York: The Edwin Mellen Press.

“Living World.” Manincor. Accessed 12 September, 2011. http://www.manincor.it/en/living-world.html

Lupke, Christopher, ed. 2008. New Perspectives on Contemporary Chinese Poetry. New York: Palgrave Macmillan.

Marinoni, Mingazzini Rosa, and Salmoiraghi, Luciana. 1992. A Mirror of the Times. Napoli: Morano editore.

Maxwell, Desmond Ernest Stewart.1969. The Poetry of T.S. Eliot. London: Routledge and Kegan Paul.

"Poems by Gu Cheng." Translated by Gordon T. Osing and De-An Wu Swihart. Accessed 12 September, 2011. http://www.shigeku.org/xlib/lingshidao/hanshi/gucheng.htm

Sullivan, Sheila. ed. 1973. Critics on T.S. Eliot. Plymouth: George Allen and Unwin. 